\title{
Rancang Bangun Sistem Klinik Fisioterapi (Studi Kasus: VISIC Surabaya)
}

\author{
Devi Dwi Purwanto ${ }^{1 *}$, Jimmy Tegarianto ${ }^{2}$ \\ ${ }^{1,2}$ Program Studi Sistem Informasi, Institut Sains dan Teknologi Terpadu Surabaya, Surabaya, Jawa Timur \\ Email: ${ }^{*}$ devi@stts.edu, 2jimmy.tegarrianto@gmail.com,
}

(Naskah masuk: 13 Jan 2021, direvisi: 3 Feb 2021, diterima: 9 Feb 2021)

\begin{abstract}
Abstrak
VISIC Surabaya merupakan klinik fisioterapis yang berfokus menangani pasien cedera pasca olahraga. Di era persaingan bisnis yang mengandalkan perkembangan teknologi, saat ini VISIC memiliki kendala dalam menyediakan pelayanan yang cepat dan tepat, dimana pelayanan masih menggunakan sistem manual yakni dengan dicatat dalam buku tulis. Oleh karena itu untuk memberikan pelayanan yang lebih baik maka diperlukan suatu sistem informasi untuk membantu baik pendaftaran, pencatatan hingga pelaporan seluruh transaksi yang ada di VISIC Surabaya. Aplikasi klinik VISIC Surabaya merupakan suatu aplikasi berbasis website menggunakan framework Codeigniter yang ditujukan untuk membantu pasien sehingga dapat melakukan pendaftaran secara online, melihat history pemeriksaan, dan mengubah jadwal kedatangan. Untuk fisioterapis, aplikasi ini bertujuan untuk membantu memberikan kemudahan dalam memberikan jadwal praktek ke pasien, pencatatan rekam medis, dan kemudahan dalam pencatatan pemeriksaan pasien dengan gambar menggunakan HTML 5 Canvas. Sedangkan untuk petugas, aplikasi ini bertujuan untuk memudahkan pencatatan barang, melihat kedatangan pasien, melakukan check in kedatangan, mencetak invoice hingga pelaporan. Hasil pengujian menggunakan metode Blackbox menunjukkan bahwa aplikasi ini dapat berjalan dengan baik pada browser umum seperti Chrome, Mozilla, dan lain lain. Berdasarkan hasil pengujian melalui kuesioner didapatkan hasil $80 \%$ aplikasi VISIC mampu menangani masalah dan memberikan pelayanan yang cepat dengan memberikan fitur reservasi online serta 73,3\% menghasilkan informasi yang akurat dalam hal titik terapi yang dilakukan oleh fisioterapis.
\end{abstract}

Kata Kunci: Klinik, Fisioterapis, Codeigniter, HTML5

\section{Physiotherapy Clinic System Design (Case Study: VISIC Surabaya)}

\begin{abstract}
VISIC Surabaya is a physiotherapist clinic that focuses on treating post-Sports injured patients. In the era of business competition that relies on technological developments, VISIC has an obstacle in providing fast and precise services. Where the current service still uses a manual system, namely by recording it in all notebooks. Therefore, to provide a better service, an information system is needed to help both registrations, recording and reporting for all transactions in VISIC Surabaya. The VISIC Surabaya clinic application is a website-based application using the Codeigniter framework which is intended to help patients so they can register online, view examination history, and change arrival schedules. For physiotherapists, this application aims to help provide convenience in providing practice schedules to patients, recording medical records and easiness in recording patient examinations with images using HTML 5 Canvas. For officers, this application aims to make it easier to record items, see patient arrivals, check in on arrival, and print invoices to reporting. The test results using the Blackbox method show that this application can run well on general browsers such as Chrome, Mozilla, and others. Based on the results of testing through questionnaires, it was found that $80 \%$ of the VISIC application was able to handle problems and provided fast service through online reservation feature. Also $73.3 \%$ resulted accurate information in terms of therapy points was done by physiotherapist.
\end{abstract}

Keywords: Clinic, Physiotherapist, Codeigniter, HTML5 


\section{PENDAHULUAN}

Vincentius Sport Injury Clinic (VISIC) adalah klinik fisioterapi yang menangani cidera pasca olah raga. VISIC berada di Gedung STIKES Katolik St. Vincentius a Paulo Surabaya Lt .4 Jalan Jambi 12 - 18 Surabaya. VISIC sendiri dibentuk sebagai badan usaha STIKES Katolik St. Vincentius a Paulo dan bekerja sama dengan Rumah Sakit St. Vincentius a Paulo Surabaya (RKZ). Permasalahan yang terjadi adalah VISIC Surabaya belum memiliki sistem yang mendukung administrasi seperti pendaftaran, rekam medik, administrasi keuangan yang mana sangat diperlukan dalam melakukan pelayanan dan pencatatan setiap kegiatan praktik di poliklinik. Sistem yang sedang berjalan saat ini, untuk setiap pencatatan jadwal kedatangan dan penghitungan pembayaran dan bukti nota pembayaran dilakukan secara manual. Hal ini mengakibatkan kinerja petugas atau fisioterapis tidak efisien dan tidak tepat dalam melakukan tindakan. Selain itu juga mengakibatkan kepercayaan dan kepuasan pasien terhadap pelayanan yang diberikan rumah sakit akan menurun.

Oleh sebab itu dibutuhkan suatu sistem yang terkomputerisasi dan terintegrasi untuk menangani masalah seperti yang diuraikan di atas. Sistem poliklinik VISIC merupakan sistem yang dirancang dan dibangun untuk mengatasi masalah administrasi, dimana dalam sistem ini pada proses reservasi dapat dilakukan secara online sehingga pasien tidak perlu mengantri dan juga petugas dapat memasukkan rekam medis secara lebih terstruktur. Selain itu sistem pembayaran dan pencetakan nota yang otomatis memberikan kemudahan bagi petugas dalam melakukan penagihan terhadap tindakan yang dilakukan dan pasien juga dapat melihat history tindakan fisioterapis yang telah dilakukan.

\section{TINJAUAN PUSTAKA}

Pada tinjauan pustaka ini akan dibahas mengenai teori teori yang digunakan sebagai landasan dalam pembuatan aplikasi, adapun penjelasan mencakup hal hal sebagai berikut:

\section{A. Framework Codeigniter}

Framework atau dalam Bahasa Indonesia dapat diartikan sebagai "kerangka kerja" merupakan kumpulan dari fungsifungsi atau prosedur-prosedur dan kelas-kelas untuk tujuan tertentu yang sudah siap digunakan sehingga mempermudah dan mempercepat pekerjaan seorang programmer, dimana programmer tidak membuat fungsi dan kelas dari awal. Codeigniter adalah sebuah framework web application network yang bersifat open-source yang digunakan untuk membangun aplikasi PHP dinamis [1].

Codeigniter mengimplementasikan pola Model - View Controller (MVC). Ini merupakan metode pengorganisasian file dalam membangun sebuah website applications [2]. MVC merupakan konsep yang cukup popular dalam pembangunan aplikasi web, berawal dari Bahasa pemrograman Small Talk, yang memisahkan business logic (alur piker), data logic (penyimpanan data), dan presentation logic (antarmuka aplikasi). Secara sederhana MVC ini memisahkan antara desain, data dan proses dalam membangun MVC ada 3 komponen utama yang penting yakni:

- Model, biasanya berhubungan dengan data dan interaksi ke database atau web service. Model mempresentasikan struktur data dari aplikasi yang bisa berupa basis data maupun data lain. Biasanya di dalam model berisikan class atau fungsi untuk mengambil, melakukan update, dan menghapus data website

- View, merupakan bagian yang menangani presentation logic. Pada suatu aplikasi web, bagian ini biasanya berupa file HTML, yang diatur oleh controller. View sendiri berfungsi untuk menerima dan mempresentasikan data hasil dari model dan controller kepada user. View tidak memiliki akses langsung terhadap bagian model.

- Controller, merupakan bagian yang mengatur hubungan antara bagian model dan bagian view. Pada controller terdapat class-class dan fungsi fungsi yang memproses permintaan dari view ke dalam struktur data di dalam model.

\section{B. HTML 5 Canvas}

Dikutip dari Wikipedia, Hypertext Markup Language atau dikenal dengan HTML adalah sebuah bahasa markup yang digunakan untuk membuat sebuah halaman website, menampilkan bebagai informasi di dalam sebuah penjelajah web internet dan pemformat hiperteks sederhana yang ditulis dalam berkas format ASCII agar dapat menghasilkan tampilan wujud terintergrasi [3].

Menurut Williams dan Sawyer (2007) Hypertext Markup Language (HTML) adalah sekumpulan perintah khusus (disebut "tag" atau "markup") yang dipakai untuk menentukan struktur, bentuk, dan link pada dokumen ke dokumen multimedia lain di website [4].

HTML 5 adalah versi terakhir dari HTML. Ada beberapa aturan yang diterapkan di HTML 5 seperti fitur-fitur baru harus berbasis HTML, CSS, DOM, dan Javascript. Penanganan kesalahan (Error Handling) yang lebih baik serta di HTML 5 telah ditambahkan juga beberapa fitur baru seperti canvas yang digunakan untuk menampilkan gambar dan animasi, mendukung video dan animasi, dan juga adanya struktur elemen baru seperti artikel, header, section, dan footer yang memberikan kemudahan dalam menempatkan format CSS.

Dikutip dari Wikipedia, "the canvas element is part of HTML 5 and allow for dynamic script tabel rendering of $2 D$ shape and bitmap images", yang berarti canvas elemen ini merupakan bagian dari HTML 5 dimana elemen canvas memungkinkan untuk menggunakan dynamic script untuk melakukan render dalam bentuk 2D atau pun gambar bitmap [5][6]. Menurut Tim EMS (2016), canvas merupakan salah satu fitur baru HTML 5 yang berguna menampillkan gambar melalui program dengan elemen <canvas>, dimana elemen ini digunakan untuk mengambar grafis secara on the fly menggunakan scripting (yang paling lazim adalah javascript). Canvas memiliki beberapa method untuk 
menggambar path, box, circle, character dan menambahkan image [7][8].

\section{METODE PERANCANGAN SISTEM}

Dalam melakukan perancangan suatu sistem diperlukan beberapa metode. Berikut adalah beberapa metode dalam perancangan sistem klinik fisioterapi.

\section{A. Tahap Analisis}

Dalam tahap perancangan dilakukan dengan cara observasi ke klinik "VISIC" Surabaya atau pun dengan cara wawancara dengan pengelola dan seluruh pihak-pihak yang berkaitan dengan manajemen klinik VISIC sehingga menghasilkan suatu informasi berupa suatu alur kerja dari beberapa bagian yang terdapat dalam klinik VISIC. Berikut di Gambar 1 adalah gambaran tahap analisis sistem klinik fisioterapi.

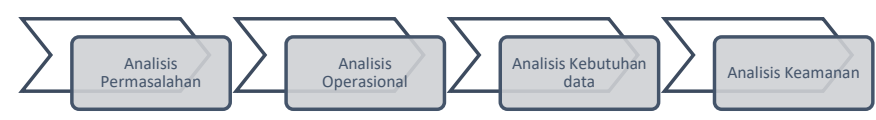

Gambar 1. Tahap Analisis Sistem

B. Tahap Rancangan Desain

Pada tahap desain ini dilakukan dengan melakukan desain sistem berupa Flow Diagram diikuti dengan Context Diagram, ERD serta rancangan antarmuka atau interface.

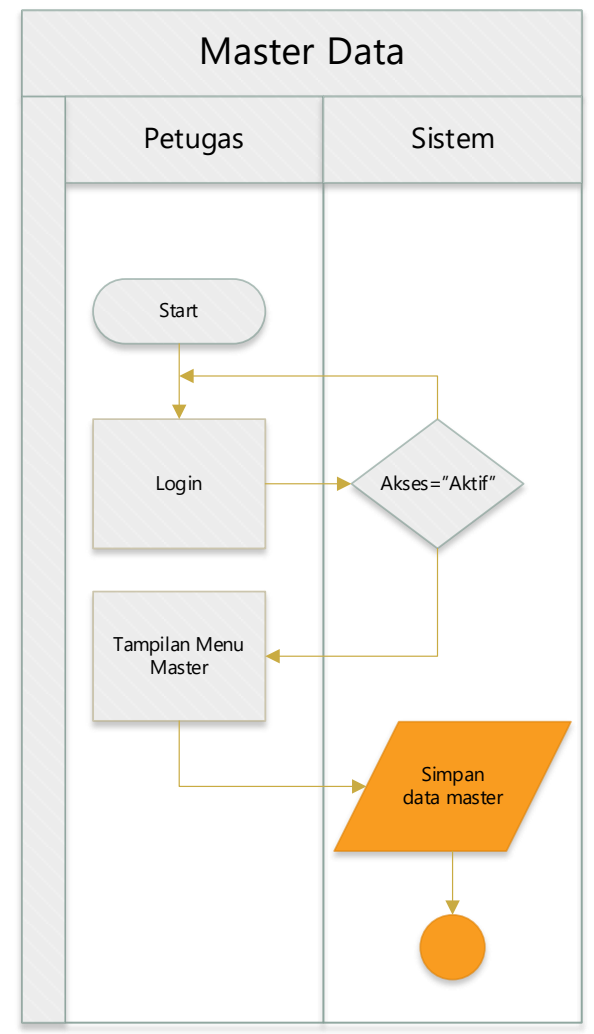

Gambar 2. Flow Diagram Master Data
Pada Gambar 2 tampak Flow Diagram input master, petugas akan login ke dalam sistem. Nantinya sistem akan melakukan pengecekan apakah pengguna diberikan hak akses untuk mengakses menu master. Jika ya, maka sistem akan menampilkan menu master, setelah itu petugas akan menginputkan data master.

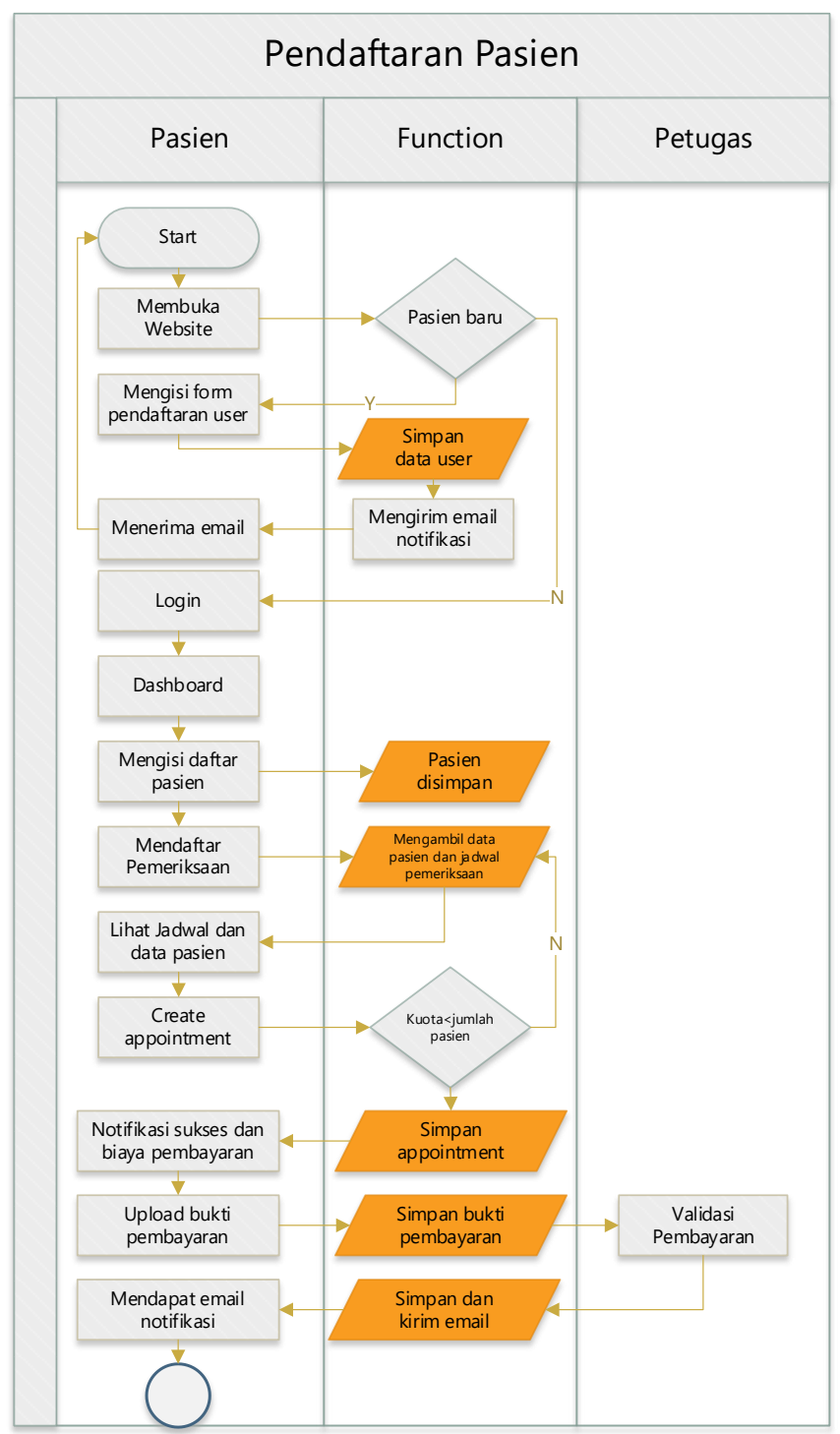

Gambar 3. Flow Diagram Pendaftaran Pasien

Pada Gambar 3, Flow Diagram pendaftaran pasien berisikan alur pendaftaran pasien dari pendaftaran user lalu memasukkan daftar pasien (user bisa mendaftarkan lebih dari 1 pasien), melakukan appointment hingga validasi pembayaran oleh pihak petugas. 


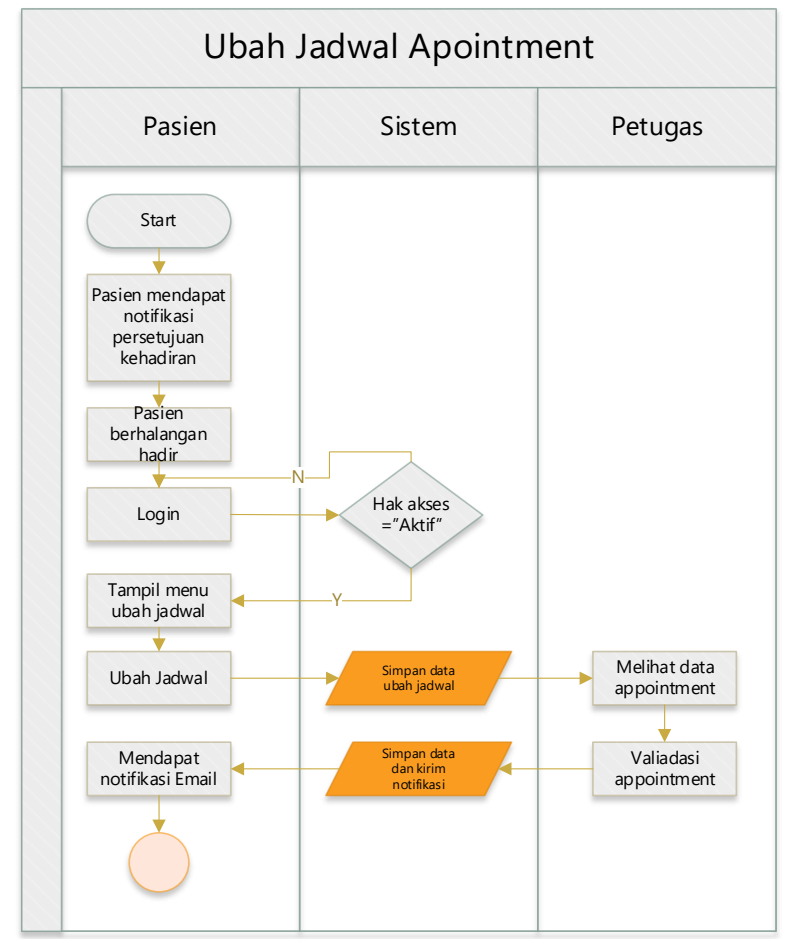

Gambar 4. Flow Diagram Ubah Jadwal Appointment

Pada Gambar 4, Flow Diagram ubah jadwal appointment berisikan alur dari pasien yang sudah berstatus divalidasi pada proses pendaftaran sehingga pasien dapat melakukan reschedule jika pasien tersebut berhalangan hadir.

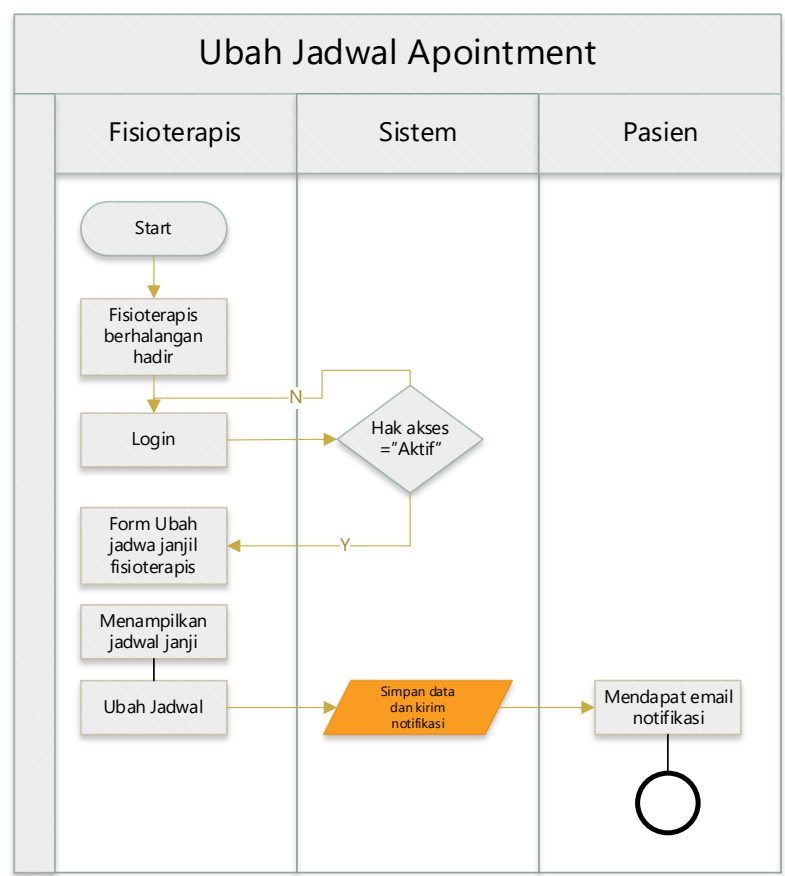

Gambar 5. Flow Diagram Reschedule Fisioterapis

Pada Gambar 5, Flow Diagram untuk reschedule fisioterapis berisikan alur jika fisioterapis berhalangan hadir pada saat waktu pemeriksaan.

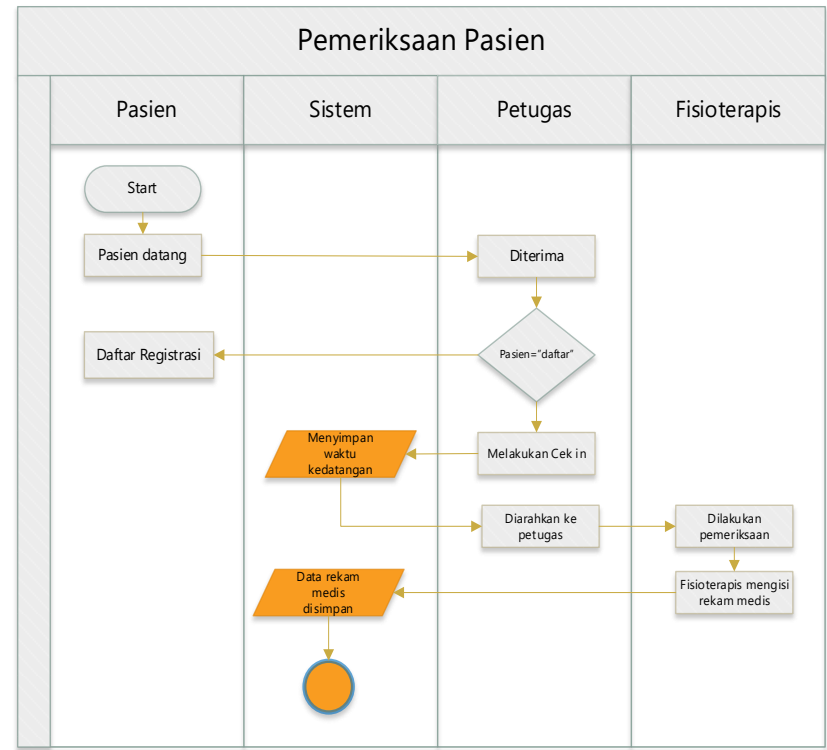

Gambar 6. Flow Diagram Pemeriksaan Pasien

Pada Gambar 6, Flow Diagram pemeriksaan pasien berisikan alur saat pasien melakukan pemeriksaan. Pasien datang di waktu yang ditentukan, kemudian akan dilakukan pengecekan oleh petugas apakah pasien apakah sudah melakukan janji atau belum. Jika belum maka pasien diminta untuk melakukan registasi terlebih dahulu. Jika sudah petugas melakukan check in pada sistem dan sistem akan mencatat waktu kedatangan dari pasien. Setelah check in petugas fisioterapis akan melakukan pemeriksaan dan jika sudah selesai melakukan pemeriksaan maka petugas dapat langsung mengisi rekam medis dan melakukan penyimpanan data rekam medis pada pasien.

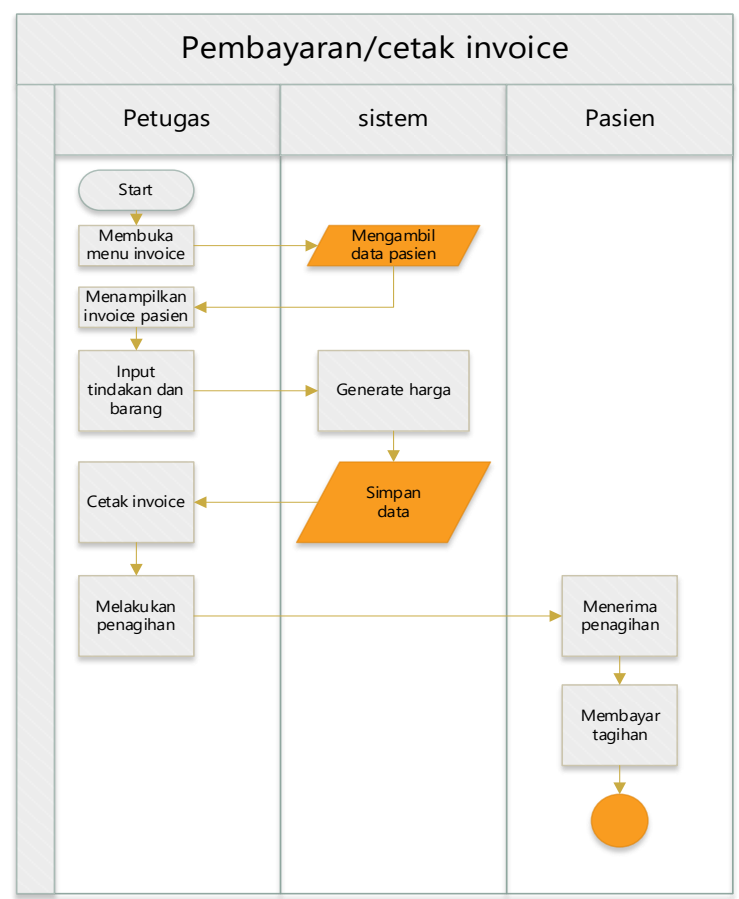

Gambar 7. Flow Diagram Pembayaran/Cetak Invoice 
Pada Gambar 7, Flow Diagram pembayaran berisikan alur pembayaran dari pasien setelah selesai melakukan pemeriksaan. Setelah pasien melakukan pemeriksaan, petugas akan membuka menu invoice. Di dalam menu invoice terdapat data pasien yang sudah diperiksa kemudian petugas memilih nama pasien lalu form invoice diisi dengan harga dan tindakan yang sudah terisi dari form sebelumnya. Kemudian petugas mencetak bukti invoice dan diserahkan kepada pasien. Pada invoice tersebut disertakan biaya jasa terapi yang dilakukan oleh fisioterapis dan obat yang digunakan dalam pemberian terapi.

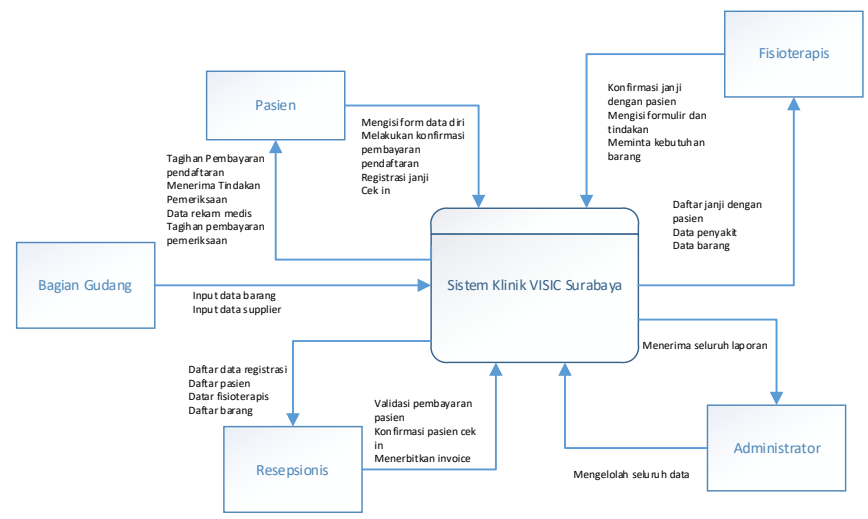

Gambar 8. Context Diagram

Tahap selanjutnya adalah menggambarkan sel, menggambarkan seluruh jaringan secara umum, baik masukan maupun keluaran dari sistem (hubungan antara sistem keluar, sistem ke dalam) dan juga menggambarkan hubungan antar komponen dengan sistem yang disebut dengan context diagram seperti terlihat pada Gambar 8.

Data Flow Diagram (DFD) atau Diagram Aliran Data (DAD) merupakan gambaran sistem secara lengkap, baik sistem yang sudah ada maupun sistem yang akan dirancang. Berikut ini merupakan DFD yang memberikan informasi mengenai aliran data yang lebih rinci daripada diagram konteks. DFD yang disajikan meliputi DFD level 0 hingga DFD level 2. DFD level 1 yang dibuat meliputi pengolahan pendaftaran, penanganan pasien, dan pengaturan jadwal pasien. Sedangkan DFD level 2 yang dirancang adalah proses pengolahan tindakan yang diberikan fisioterapis pada pasien.

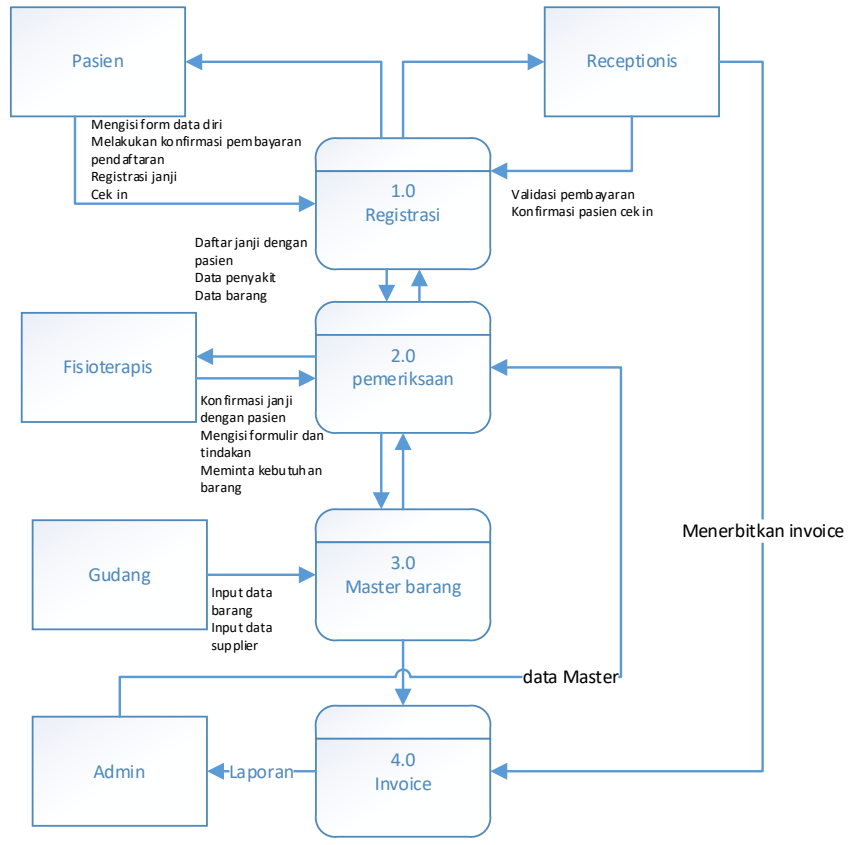

Gambar 9. DFD Level 0

Pada Gambar 9, merupakan DFD Level 0 pengembangan dari diagram konteks dimana DFD level 0 mengambarkan desain sistem secara umum.

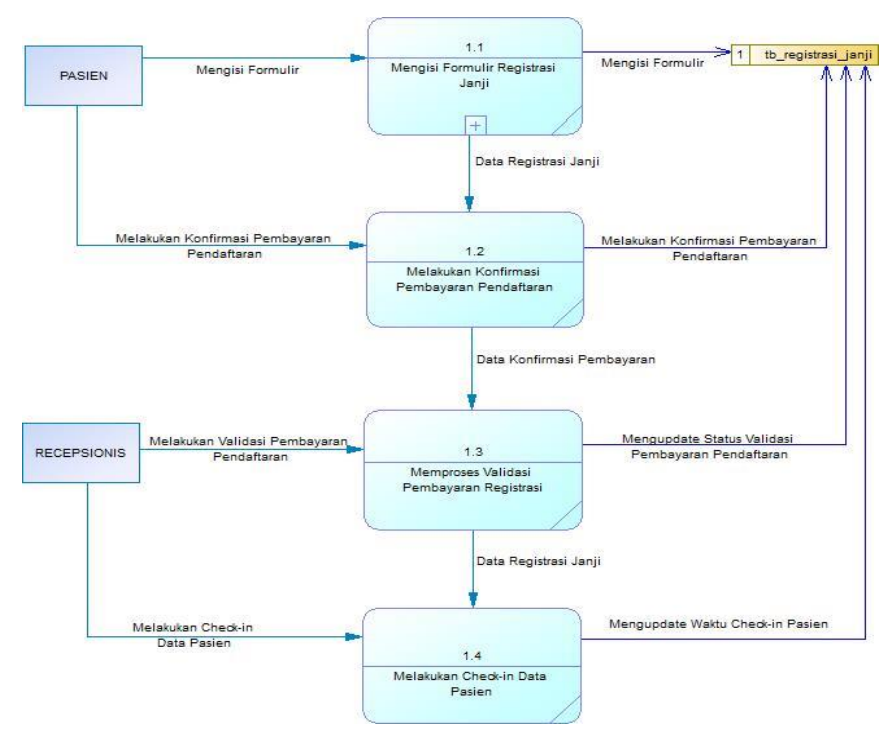

Gambar 10. DFD Level 1 Pengolahan Pendaftaran

Pada gambar 10, merupakan DFD level 1 untuk proses pengolahan pendaftaran yang berfungsi untuk memberikan alur data pengolahan pendaftaran pada aplikasi klinik VISIC Surabaya. 


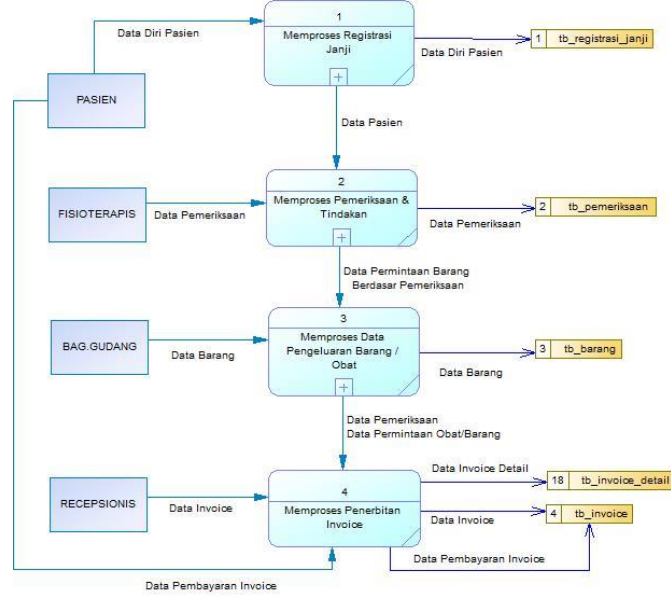

Gambar 11. DFD Level 1 Penanganan pasien

Pada Gambar 11, merupakan DFD level 1 proses pengolahan penanganan pasien yang berfungsi untuk memberikan alur data pengolahan penanganan pasien pada aplikasi klinik VISIC Surabaya.

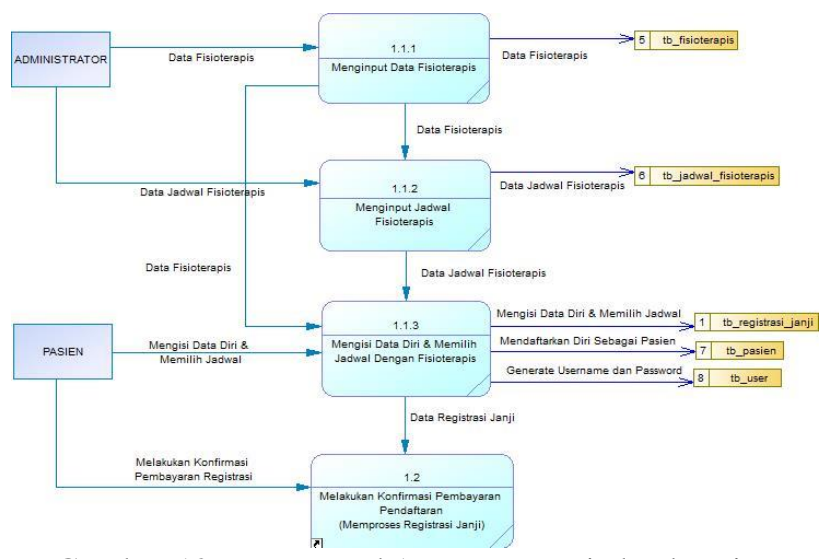

Gambar 12. DFD Level 1 Pengaturan jadwal pasien

Pada Gambar 12, merupakan DFD level 2 proses pengolahan jadwal dan pasien yang berfungsi untuk memberikan alur data pengolahan jadwal dan pasien pada aplikasi klinik VISIC Surabaya.

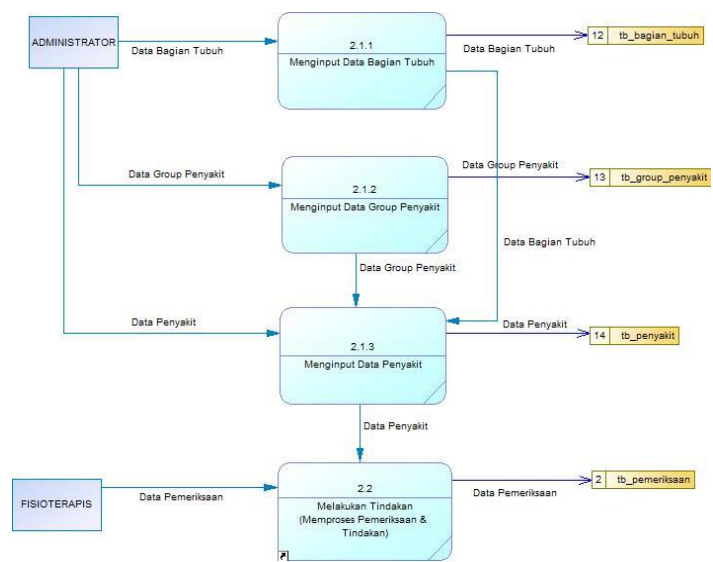

Gambar 13. DFD Level 2 Proses Pengolahan Tindakan
Pada Gambar 13, merupakan DFD level 2 pengolahan tindakan berfungsi untuk memberikan alur data pengolahan tindakan pada aplikasi klinik VISIC Surabaya.

\section{IMPLEMENTASI}

Pada tahap ini dilakukan impelementasi pembuatan sistem terhadap rancangan-rancangan yang telah didefinisikan sebelumnya. Pembuatan sistem ini menggunakan bahasa pemrograman PHP dengan framework Codeigniter. Pada Gambar 14 dapat dilihat tampilan master pasien.

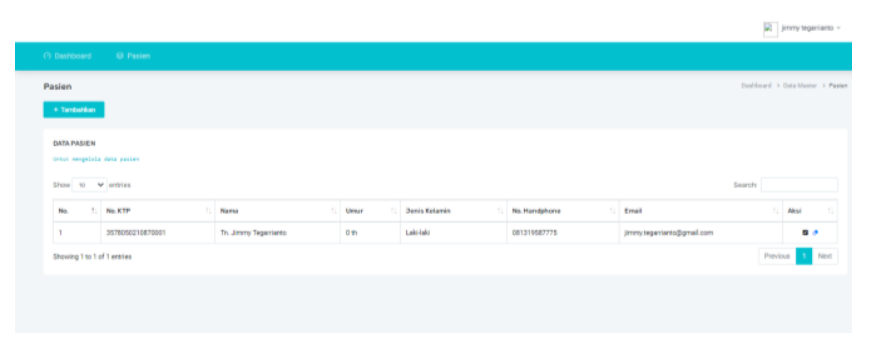

Gambar 14. Tambah Pasien

Setelah menambah pasien user dapat membuat janji dengan fisioterapi dengan masuk ke menu pendaftaran. Pada Gambar 15 adalah tampilan dari form pendaftaran.

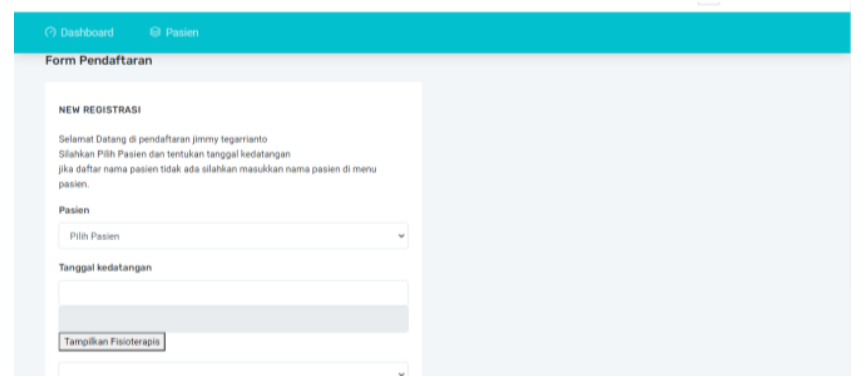

Gambar 15. Tambah Pasien dan Pilih Jadwal

Pada Gambar 16 merupakan form untuk upload bukti pembayaran saat pasien melakukan pendaftaran di klinik "VISIC" Surabaya.

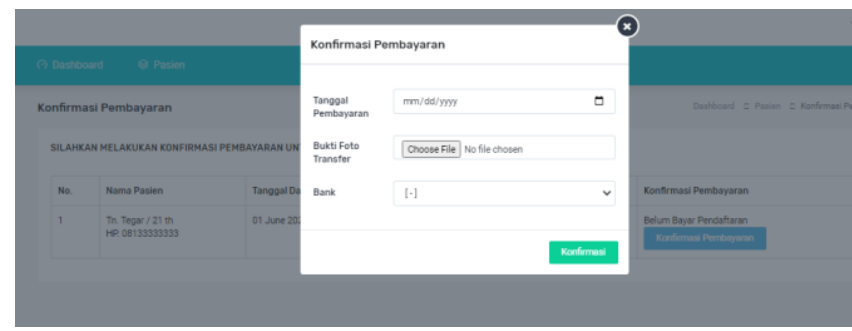

Gambar 16. Antarmuka Konfirmasi Pembayaran

Pada tampilan menu validasi pembayaran oleh petugas dapat dibuka melalui menu validasi pembayaran, menu ini berfungsi untuk melihat pasien yang sudah melakukan pembayaran biaya pendaftaran. Implementasi antarmuka form validasi pembayaran dapat dilihat pada Gambar 17. 


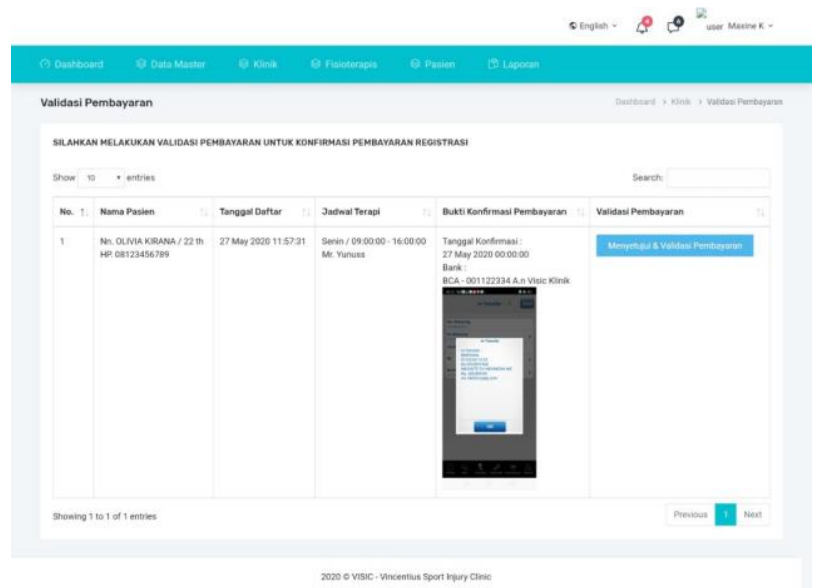

Gambar 17. Implementasi Form Validasi Pembayaran

Pihak fisioterapis dapat melihat daftar pasien yang hendak ditangani dalam form pemeriksaan. Pada Gambar 18 merupakan impementasi antar muka pemeriksaan-daftar pasien.

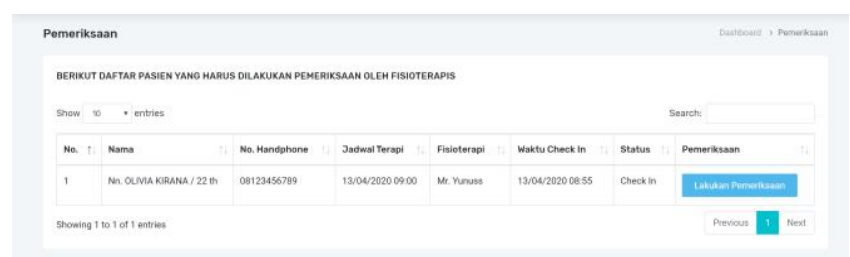

Gambar 18. Implementasi Pemeriksaan-Daftar Pasien

Hanya fisioterapis yang dapat melakukan pemeriksaan, Pada Gambar 19 ditunjukkan antarmuka pemeriksaan bagian tubuh, terdapat menu lakukan pemeriksaan. Dengan memilih menu tersebut maka akan ditampilkan anatomi tubuh manusia.

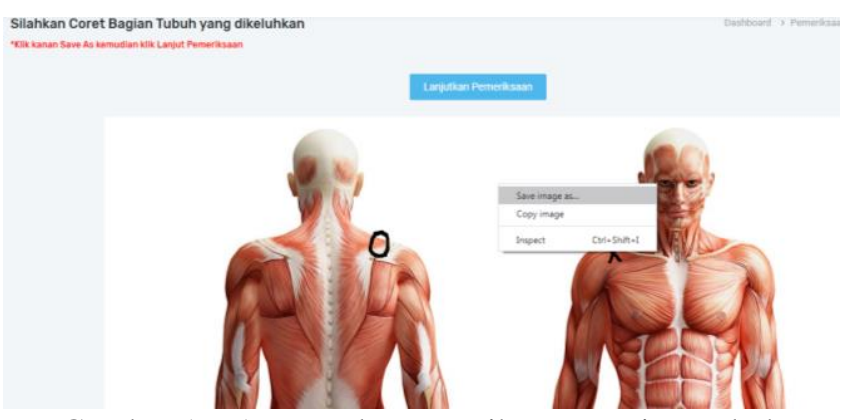

Gambar 19. Antarmuka Pemeriksaan Bagian Tubuh

Pihak fisioterapis bisa langsung melingkari atau memberikan tanda silang bagian tubuh yang sakit kemudian melakukan save pada gambar dengan klik kanan save as, dan menekan tombol lanjutkan pemeriksaan seperti pada Gambar 20. Pencatatan bagian tubuh yang diberikan terapi ini dibutuhkan mengingat keterlibatan dalam masalah keselamatan olahraga sangat diperlukan untuk pelaksanaan tindakan program yang terkoordinasi [9] dan dapat ditangani oleh beberapa fisioterapis.

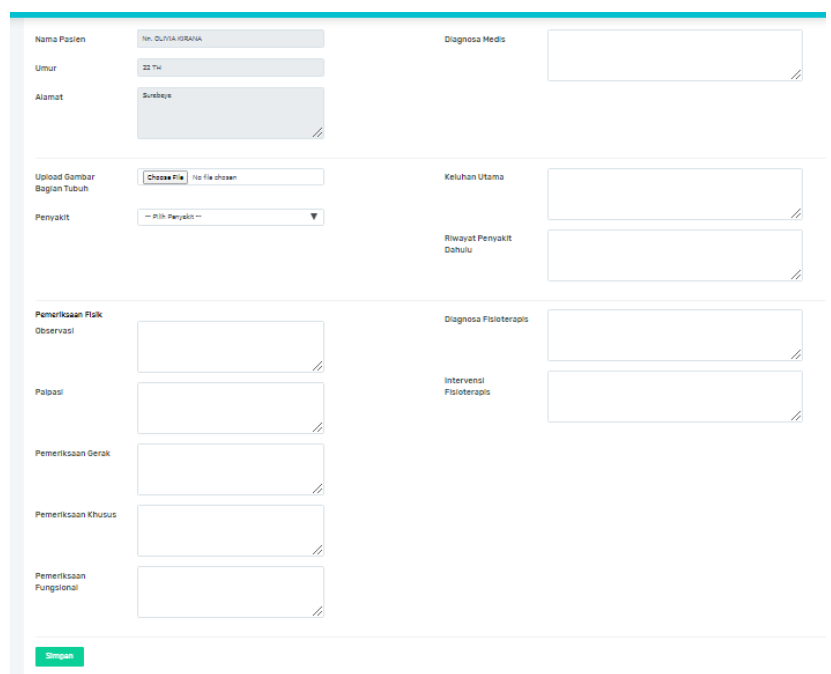

Gambar 20. Antarmuka Pemeriksaan

Jika sudah melakukan pemeriksaan maka petugas akan melakukan pembuatan invoice dengan memasukkan data seperti Gambar 21.

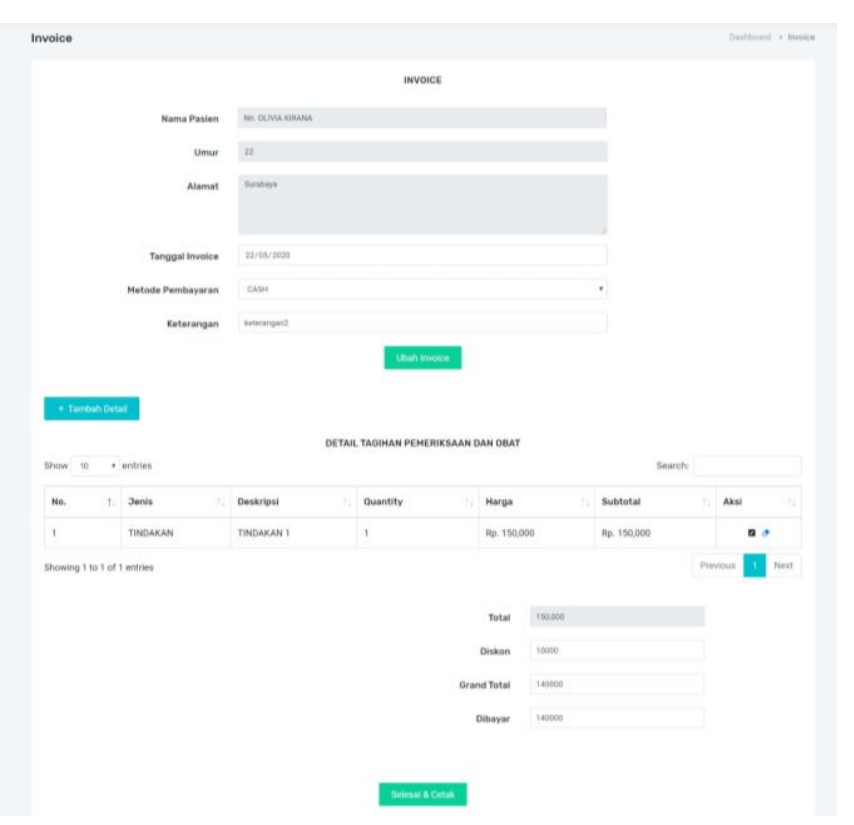

Gambar 21. Antarmuka Form Invoice

Dari hasil form invoice ini nantinya akan ditampilkan invoice yang dapat dicetak dan diserahkan ke pasien.

\section{UJI COBA}

Uji coba pada sistem klinik VISIC surabaya meliputi uji coba secara langsung pada klinik dan uji coba yang dilakukan oleh beberapa user yang bertindak sebagai pegawai dan fisioterapis. 
A. Hasil Pengujian Kuesioner

Pengujian kuesioner adalah media yang digunakan untuk mendapatkan penilaian dari pengguna aplikasi klinik baik petugas, fisioterapis, maupun pasien. Berdasarkan hasil kuesioner tersebut akan dilakukan perhitungan agar bisa diambil kesimpulan dari penerapan aplikasi yang dibangun. Kuesioner terdiri dari atas 2 tipe kuesioner yakni kuesioner khusus untuk admin dan kuesioner khusus untuk user/ pasien. Skor penilaian yang diberikan dengan menggunakan skala likert pada setiap pertanyaan yang dapat dilihat pada Tabel 1.

Tabel 1. Skor Penilaian Kuesioner

\begin{tabular}{llc}
\hline Skala Jawaban & \multicolumn{1}{c}{ Keterangan } & Skor \\
\hline SB & Sangat baik & 5 \\
\hline B & Baik & 4 \\
\hline C & Cukup & 3 \\
\hline K & Kurang & 2 \\
\hline SK & Sangat Kurang & 1 \\
\hline
\end{tabular}

Berdasarkan data hasil kuesioner tersebut dapat dicari persentase masing masing jawaban dengan menggunakan rumus (1).

$Y=\frac{\mathrm{x}}{\text { Skor ideal }} \times 100$

Keterangan:

$\mathrm{Y} \quad$ : Nilai persentase yang dicari

$\mathrm{X} \quad$ : Jumlah nilai kategori jawaban yang dilakukan dengan frekuensi $\left(\sum=\mathrm{N} \times \mathrm{R}\right)$

$\mathrm{N} \quad$ : Nilai setiap jawaban

$\mathrm{R} \quad$ : Frekuensi

Skor Ideal: Nilai Tinggi dikalikan dengan jumlah sampel $(5 \times 30=150)$

Setelah diperoleh nilai $\mathrm{Y}$, maka interpretasi nilai atau skor dapat dilihat pada Gambar 22 berikut:

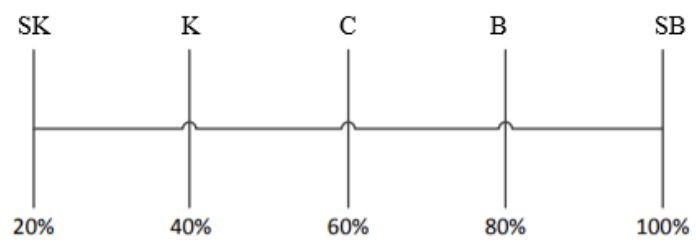

Gambar 22. Skala Hasil

B. Kuesioner Admin

Kuesioner admin adalah kuesioner yang ditujukan untuk bagian manajemen yakni, pimpinan atau pun pihak fisioterapis. Dalam kuesioner ini terdapat 10 pertanyaan yang bertujuan untuk melihat seberapa efektif program yang sudah dibuat. Berikut pada Tabel 2 adalah hasil dari kuesioner admin:
Tabel 2. Hasil Kuesioner Admin

\begin{tabular}{|c|c|c|}
\hline No & Pertanyaan & Hasil \\
\hline 1 & $\begin{array}{l}\text { Sistem informasi Klinik VISIC Surabaya mampu } \\
\text { menangani masalah dalam memberikan pelayanan } \\
\text { pada konsumen dengan segera. }\end{array}$ & $80 \%$ \\
\hline 2 & $\begin{array}{l}\text { Sistem informasi Klinik VISIC Surabaya dapat } \\
\text { memberikan pelayanan secara cepat. }\end{array}$ & $80 \%$ \\
\hline 3 & $\begin{array}{l}\text { Sistem informasi Klinik VISIC Surabaya dapat } \\
\text { menyediakan jasa sesuai yang dijanjikan dengan } \\
\text { akurat. }\end{array}$ & $80 \%$ \\
\hline 4 & $\begin{array}{l}\text { Sistem informasi Klinik VISIC Surabaya dapat } \\
\text { menjamin keamanan data pada saat data disimpan }\end{array}$ & $73,3 \%$ \\
\hline 5 & $\begin{array}{l}\text { Sistem informasi Klinik VISIC Surabaya memiliki } \\
\text { kecepatan akses saat digunakan. }\end{array}$ & $73,3 \%$ \\
\hline 6 & $\begin{array}{l}\text { Sistem informasi Klinik VISIC Surabaya memiliki } \\
\text { kemudahan untuk diakses kapanpun saat dibutuhkan. }\end{array}$ & $80 \%$ \\
\hline 7 & $\begin{array}{l}\text { Sistem informasi Klinik VISIC Surabaya } \\
\text { menghasilkan informasi yang akurat. }\end{array}$ & $73,3 \%$ \\
\hline 8 & $\begin{array}{l}\text { Sistem informasi Klinik VISIC Surabaya dapat } \\
\text { menyajikan laporan sesuai kebutuhan perusahaan. }\end{array}$ & $66,6 \%$ \\
\hline 9 & $\begin{array}{l}\text { Format (sisi tampilan) sistem informasi Klinik } \\
\text { VISIC surabaya mudah ketika digunakan. }\end{array}$ & $73,3 \%$ \\
\hline 10 & $\begin{array}{l}\text { Cara kerja sistem informasi Klinik VISIC Surabaya } \\
\text { mudah untuk dipahami. }\end{array}$ & $73,3 \%$ \\
\hline
\end{tabular}

\section{KESIMPULAN}

Pembuatan aplikasi sistem informasi klinik "VISIC" Surabaya bertujuan untuk mempermudah dalam menjalankan bisnis mulai dari pendaftaran, pencatatan rekam medis, pencatatan barang, pencatatan transaksi hingga membuat laporan. Pengumpulan data dilakukan dengan melakukan peninjauan ke lapangan dengan melihat sistem kerja dari klinik "VISIC" Surabaya dalam melakukan pendaftaran, penanganan serta melakukan analisis dokumen seperti dokumen pemeriksaan, bukti pembayaran, melakukan studi pustaka yang berkaitan dengan aplikasi yang akan dibuat dan melakukan wawancara dengan pihak-pihak yang berhubungan dengan klinik VISIC.

Pengujian dilakukan dengan menggunakan metode Blackbox testing, berdasarkan pengujian maka diperoleh kesimpulan bahwa aplikasi yang dibangun telah sesuai dengan kebutuhan fungsional. Berdasarkan hasil pengujian melalui kuesioner didapatkan bahwa $80 \%$ aplikasi VISIC mampu menangani masalah dan memberikan pelayanan yang cepat dengan memberikan fitur reservasi online sehingga pasien tidak membuang waktu untuk mengantri. Akurasi pemberian informasi sebesar $73,3 \%$, dimana dapat memudahkan mengetahui titik terapi yang dilakukan oleh fisioterapis.

\section{REFERENSI}

[1] IDCloudHost. (2017). Belajar Cepat Framework Codeigniter Untuk Pemula. Diakses dari https://idcloudhost.com/wp-content/uploads/2017/08/ Panduan-Belajar-Cepat-Framework-Codeigniter-untukPemula-IDCloudHost.pdf. pada tanggal 19 Mei 2020

[2] Basuki, A. (2010). Membangun Web Berbasis PHP dengan Framework Codeigniter. Yogyakarta: Lokomedia. 
[3] Wikipedia. (2020). HTML. Diakses dari: https://id.wikipedia.org/wiki/HTML pada tanggal 5 Mei 2020.

[4] Williams, B.K. \& Sawyer, S.C. (2007). Using Information Technology. Yogyakarta: Andi.

[5] Wikipedia. HTML 5 Canvas. Diakses dari: https://id.wikipedia.org/wiki/HTML5_canvas pada tanggal 5 Mei 2020.

[6] Boulos, M.N.K., Warren, J., Gong, J. \& Yue, P. (2010). Web GIS in Practice VIII: HTML5 and the Canvas Element for Interactive Online
Mapping. International Journal of Health Geographics Vol. 9.

[7] Tim EMS. (2016). All in One Web Programming. Jakarta: PT Elex Media Komputindo.

[8] Pramono I., \& Honggara E.S. (2019). Website Pemesanan Karangan Bunga Dekoratif dengan Fasilitas Kustomisasi Rangkaian. Journal of Information System,Graphics, Hospitality and Technology, Vol. 1(1), pp. 1-5.

[9] Timpka, T., Ekstrand, J. \& Svanström, L. (2006). From Sports Injury Prevention to Safety Promotion in Sports. Sports Medicine, Vol. 36, pp. 733-745. 